\title{
Kajian Operasi Pasar Komoditas Bawang Putih di Provinsi Jambi
}

\author{
Nida Kemala \\ Program Studi Agribisnis Fakultas Pertanian Universitas Batanghari \\ J1. Slamet Riyadi-Broni, Jambi. 36122. Tel. +6274160103 \\ e-mail : nidakemala@yahoo.com
}

\begin{abstract}
The research was conducted with the aims as the operation describing of garlic market, garlic price and determining the duration of time required to restore its normal price. The type of data was secondaries data with applying a deststudy collection method. Data were analyzed descriptively equipped with a single sample Chi-Square non-parametric statistical test. The results of the study showed that The operation of the Garlic engaged several department e.g. Jambi Province Industry and Trade Service (Disperindag), Ministry of Trade of the Republic of Indonesia, Jambi Province Food Security Service, and Indonesian onion and tuber vegetable business association (Bahrindo). A total of 3.2 tons of imported garlic were distributed to the wholesale level at a price of Rp. 22,000 per kg, so that the price at the consumer level was Rp. 32,000 per Kg. The lowest average daily price was Rp.18,000 per Kg (in January) and the highest average price was Rp.46,419 per Kg (in May). In the period January to May, the average price increase reached $157.8 \%$, while the decline in May-December was smaller than the previous increase of only 65.9\% (Average price in December was Rp.25,800 per Kg). The price of garlic after market operations continued to show an increase not only due to the presence of Ramadan and Idul Fitri, but also the supply of garlic imports was too slow. The highest price fluctuation occurred in May where the price range was Rp.70,000 per $\mathrm{kg}$ (Rp. 30,000 to $R p .100,000 \mathrm{per} \mathrm{kg}$ ). The time required to return the price of garlic in the field to the normal price set by the government was 50 days or nearly two months from the started periode of market operations.
\end{abstract}

Keywords: garlic. price. market. Policy

\begin{abstract}
Abstrak. Penelitian dilakukan dengan tujuan untuk mendekripsikan pelaksanaan operasi pasar bawang putih dan harga bawang putih serta menentukan lama waktu yang dibutuhkan untuk mengembalikan harga normalnya. Jenis data sekunder dengan metode pengumpulkan data deststudy. Data dianalisis secara deskriptif dengan uji statistik non parametik Chi-Square cuplikan tunggal. Hasil kajian menunjukkan bahwa Pelaksanaan operasi Pasar Bawang Putih melibatkan beberapa instansi seperti Dinas Perindustrian, Perdagangan (Disperindag) Provinsi Jambi, Kementerian Perdagangan Republik Indonesia dan perkumpulan pelaku usaha bawang dan sayuran umbi Indonesia (Bahrindo). Sebanyak 3,2 ton bawang putih impor didistribusikan ke tingkat grosir dengan harga Rp.22.000 per Kg sehingga harga di tingkat konsumen menjadi Rp. 32.000 per Kg. Harga rata-rata harian terendah adalah Rp.18.000 per Kg (Bulan Januari) dan rata-rata tertinggi adalah Rp.46.419 per Kg (Bulan Mei). Dalam rentang waktu Januari-Mei kenaikan harga rata-rata mencapai 157,8\% sedangkan penurunan di Bulan Mei-Desember lebih kecil dari kenaikan yang terjadi sebelumnya yaitu hanya 65,9\% (Rata-rata harga pada Bulan Desember Rp.25.800 per Kg). Harga bawang putih setelah operasi pasar tetap menunjukkan peningkatan karena selain adanya bulan Ramadan dan hari besar Idul Fitri juga pasokan impor bawang putih yang lambat. Fluktuasi harga yang tertinggi terjadi di Bulan Mei dimana range harga sebesar Rp.70.000 per Kg (Rp30.000 sampai Rp100.000 per Kg). Waktu yang dibutuhkan untuk mengembalikan harga bawang putih di lapangan ke harga normal yang ditetapkan oleh pemerintah adalah 50 hari atau hampir dua bulan sejak awal pelaksanaan operasi pasar.
\end{abstract}

Kata kunci : Harga. Operasi Pasar. Bawang Putih

\section{PENDAHULUAN}

Sektor pertanian di Indonesia masih menjadi tulang punggung bagi seluruh penduduknya. Kegiatan impor komoditas pertanian menjadi perhatian menciptakan stabilitas harga. Kebijakan yang dijalankan oleh pemerintah diarahkan untuk melindungi baik konsumen maupun produsen. Harga komoditas pertanian khususnya sembako perlu diperhatikan karena berkaitan dengan stabilitas pendapatan baik konsumen maupun produsen. Bawang putih merupakan salah satu komoditas yang dibutuhkan oleh masyarakat Di lain pihak konsumsinya jauh lebih tinggi dari kemampuan produksinya. Tercatat produksi sebanyak 19.571 Ton, sedangkan konsumsi meningkat sebanyak 525.139 Ton pada tahun 2019 sehingga masih devisit sekitar 505.568 Ton (Kementan. 2018). Sedangkan menurut Samuel P. (2019) kebutuhan bawang putih mencapai rata-rata 450.000-500.000 Ton per tahun.

Ada kecenderungan peningkatan impor bawang putih 419.909 Ton pada tahun 2012 menjadi 444.300 Ton di tahun 2016 (Kementan. 2017). Produksi bawang putih dalam negeri baru mencapai 85.000 ton per tahun atau sekitar 10 persen dari kebutuhan nasional, sedangkan 90 persennya harus dipenuhi lewat impor. Meskipun pemerintah telah mengeluarkan kebijakan untuk mengimpor komoditas bawang putih. tetapi masing banyak faktor yang masih bisa mempengaruhi harga bawang putih sehingga flutuasi harganya masih terkadang di luar kendali.

Seperti yang pernah terjadi di sekitar Bulan April-Mei tahun 2019 dimana harga bawang putih melonjak naik sampai menembus angka Rp. 100.000 per Kg dari harga awal yang hanya Rp.18.000 per Kg. Tingginya harga komoditas bawang putih tersebut telah membuat masyarakat resah seiring dengan menurunnya daya beli masyarakat. Kenaikan harga bawang putih ini disebabkan oleh permintaan masyarakat menjelang hari besar yang melambung. 
Riwayat impor menunjukkan bahwa berdasarkan data BPS. impor bawang putih dari China pada Juli 2019 mencapai 71.693 ton naik dari sebelumnya sebesar 46.922 ton di Bulan Juni 2019 (Yustinus Andri DP.2019. Selain dengan mengimpor kebijakan operasi pasar juga diharapkan mampu menangani stabilitas harga bawang putih.

Kebijakan ini biasanya ditujukan untuk memantau harga komoditas strategis yang mengalami fluktuasi. Bawang putih terlihat mengalami fluktuasi yang meresahkan masyarakat sehingga pihak Dinas Perindustrian dan Perdagangan bekerjasama dengan Dinas ketahanan pangan Provinsi Jambi melakukan operasi pasar. Harga bawang putih yang sempat melambung sampai Rp. 100.000 per Kg pada Bulan Mei 2019 disebabkan oleh menipisnya stok dimana kuota hanya tersedia 25 Ton yang hanya bisa memenuhi kebutuhan seminggu kedepan karena kebutuhan mencapai 10 Ton per hari (Zulkifli. 2019). Seiring dengan tingginya konsumsi bawang putih ini maka perlu diperhatikan stabilitas harga komoditas tersebut. Dalam hal ini instrument yang bisa dipakai untuk mengendalikan harga bawang putih adalah dengan melakukan impor dan operasi pasar. Dengan demikian diharapkan harga bawang putih dapat kembali normal. Perlu dikaji jangka waktu/periode yang dibutuhkan oleh kegiatan operasi pasar untuk bisa menurunkan harga pada posisi normal. Hal ini penting untuk melihat efektifitas pelaksanaan kebijakan operasi pasar. Berdasarkan uraian di atas maka perlu dikaji hal-hal yang berkaitan dengan: gambaran pelaksanaan operasi pasar bawang putih pada tahun 2019 di Provinsi Jambi, gambaran harga bawang putih pada tahun 2019 di Provinsi Jambi dan lama waktu yang dibutuhkan dalam kebijakan operasi pasar untuk mengembalikan harga normal bawang putih pada tahun 2019 di Provinsi Jambi.

\section{METODOLOGI PENELITIAN}

Kegiatan penelitian dilakukan di sub-sistem pendukung yang akan mendukung setiap sub-sistem baik Upstream (hulu), Onfarm maupun Downstream. Penelitian ini menggambarkan kinerja kebijakan operasi pasar yang operasionalisasikan oleh kerjasama instansi Disperindag dan Dinas Tanaman Pangan dan Hortikultura melibatkan para pedagang Agen Bawang putih dan para pedagang pengecer di Jambi. Pada saat harga bawang putih tinggi yang sekaligus mengindikasikan rendahnya penawaran akan berubah menjadi rendah dengan cara operasi pasar. Operasi pasar bekerja berdasarkan hukum penawaran dengan prinsip mempengaruhi kuantitas penawaran bawang putih dengan menambah stok di

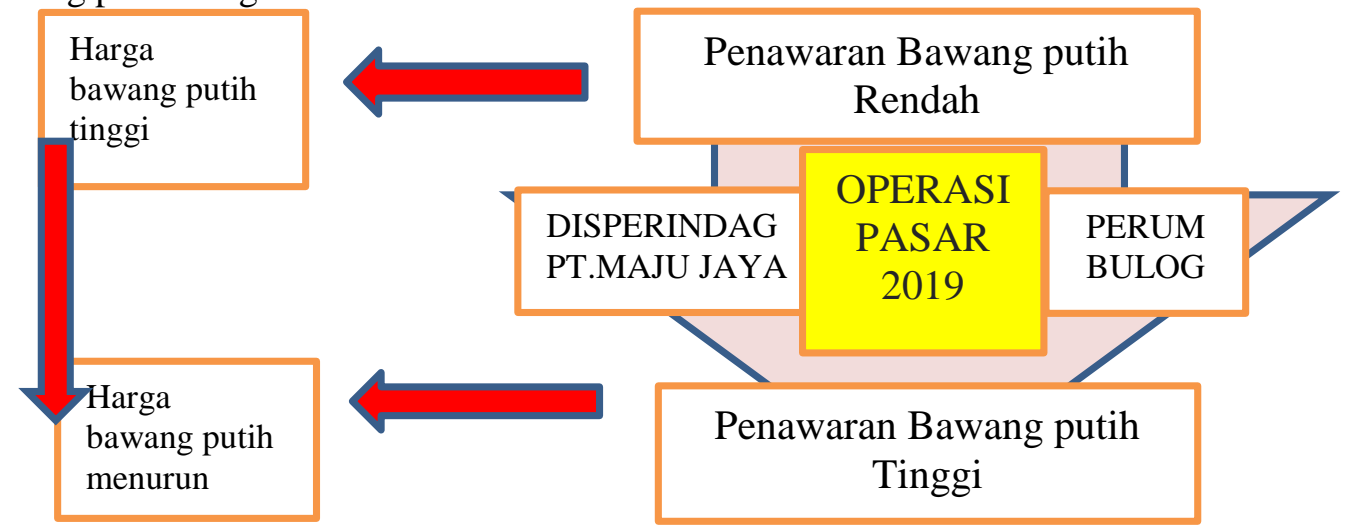

masyarakat yang pada gilirannya akan mengendalikan harga bawang putih yang asalnya tinggi menjadi menurun. Supply ini didukung selain oleh ketersediaan stok bawang putih di dalam negeri juga mayoritas masih bergantung pada aliran impor terutama dari Negara Cina. Dengan adanya operasi pasar ini diharapkan harga bawang putih dapat kembali stabil. Maka untuk melihat efektifitas kinerja operasi pasar tersebut perlu dikaji waktu yang dibutuhkan untuk segera menurunkan harga bawang putih tersebut. Hasil kajian ini dapat digunakan sebagai bahan acuan dalam mengevaluasi pelaksanaan operasi pasar berikutnya. Kajian ini difokuskan pada pelaksanaan operasi pasar, gambaran harga bawang putih dan waktu yang dibutuhkan dalam kebijakan operasi pasar untuk mengembalikan harga bawang putih ke posisi harga normal pada tahun 2019 di Provinsi Jambi.

Jenis data yang dalam penelitian ini adalah data sekunder yang bersumber dari instansi terkait (Disperidag Provinsi Jambi), laporan hasil kajian serta literatur-literatur yang berhubungan dengan tema kajian ini. Metode yang digunakan untuk mengumpulkan data dalam kajian ini menggunakan metode deskstudy yaitu dengan memilah, menyeleksi dan menganalisis data sekunder sesuai dengan kebutuhan kajian penelitian.

Sampel dalam penelitian ini adalah dari sekian banyak jenis komoditas maka salah satu komoditas pertanian strategis yang secara sengaja diambil berdasarkan pertimbangan bahwa komoditas ini adalah produk yang terpantau mengalami kenaikan harga paling ekstrim pada tahun 2019 di Kota Jambi. Secara induktif Kota Jambi sebagai pusat kota diasumsikan dapat mewakili Provinsi Jambi. Data dianalisis secara deskriptif baik kualitatif maupun kuantitatif untuk menggambarkan pelaksanaan 

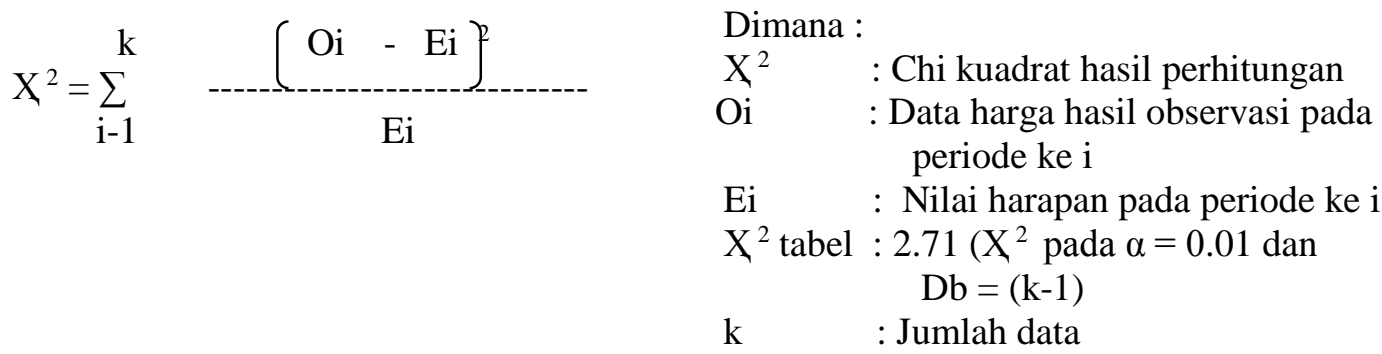

\begin{tabular}{|c|c|c|c|c|}
\hline Periode ke i (k tahun) & 1 & 2 & $\ldots$ & I \\
\hline Data Observasi (Oi) & O1 & O2 & $\ldots$ & Oi \\
\hline Nilai harapan $(\mathrm{Ei})$ & \multicolumn{5}{|c|}{$\left(\sum \mathrm{Oi}\right) / \mathrm{k}$} \\
\hline
\end{tabular}

Sedangkan untuk lama waktu yang dibutuhkan dalam kebijakan operasi pasar untuk mengembalikan harga bawang putih ke posisi harga normal dilakukan dengan menggunakan uji statistik non parametik Chi-Square cuplikan tunggal yang menurut Sudradjat SW, M (1999) diformulasikan di atas.

Hipotesis statistik:

Ho: $\mathrm{X}^{2}=0$ ( Tidak terdapat perbedaan antara harga bawang putih di lapangan dengan harga yang ditetapkan pemerintah dalam operasi pasar

Ha: $\mathrm{X}^{2} \neq 0$ ( terdapat perbedaan antara harga bawang putih di lapangan dengan harga yang ditetapkan pemerintah dalam operasi pasar).

Kaidah keputusan :

Nilai $X^{2}$ pada tabel dengan derajat bebas $(\mathrm{db})=1$ pada tingkat kepercayaan $95 \%$ adalah 3,81 . Dalam pengujian $\mathrm{X}^{2}$ hitung dibanding dengan $\mathrm{X}^{2}$ Tabel dengan kaidah keputusan sebagai berikut :

1. Terima $\mathrm{H}_{0}$ jika nilai $\mathrm{X}^{2}$ hitung $\leq \mathrm{X}^{2}$ tabel

2. Tolak $\mathrm{H}_{0}$ jika nilai $\mathrm{X}^{2}$ hitung $>\mathrm{X}^{2}$ tabel

Dalam penelitian ini waktu yang dibutuhkan untuk mencapai harga stabil menggunakan indikator saat Ho diterima, yaitu waktu dimana tidak ada perbedaan harga di lapangan dengan harga yang ditetapkan pemerintah secara statistik maka pada saat itulah jangka waktu yang dibutuhkan untuk mengembalikan harga bawang putih kembali normal.

Untuk menyamakan persepsi mengenai variabel-variabel yang diukur dalam kajian ini maka disampaikan pengertian dan batasan operasional yang digunakan sebagai berikut :

1. Operasi Pasar: Kebijakan pemerintah untuk menciptakan stabilitas harga bawang putih pada tahun 2019.

2. Waktu yang dibutuhkan dalam kebijakan operasi pasar bawang putih maksudnya adalah jangka waktu yang menunjukkan dua harga bawang putih yaitu harga yang terbentuk setelah operasi pasar sejak operasi pasar dimulai pada akhir Bulan Maret (tanggal 30 Maret) dengan harga normal yang ditetapkan oleh pemerintah (Rp. 32.000 per $\mathrm{Kg}$ ) yang tidak berbeda nyata secara statistik pada tahun 2019 .

3. Harga normal maksudnya adalah harga bawang putih yang ditetapkan oleh pemerintah dalam operasi pasar (Rp.32.000 per Kg).

\section{HASIL PENELITIAN}

\section{Gambaran Pelaksanaan Operasi Pasar Bawang Putih Tahun 2019 di Provinsi Jambi.}

Harga bawang putih ditentukan oleh kekuatan permintaan dan penawaran yang dalam hal ini penawaran disuplai dari luar negeri khususnya dari negara China. Perkembangan harga bawang putih pada tahun 2019 mulai meningkat di bulan Februari yaitu Rp.20.412 per Kg dari bulan sebelumnya yang hanya Rp.18.000. Perkembangan harga pada Tahun 2019 dapat dilihat pada Gambar 1. Peningkatan harga ini disebabkan oleh adanya permintaan yang meningkat ditengah ketersediaan stok yang kurang. 


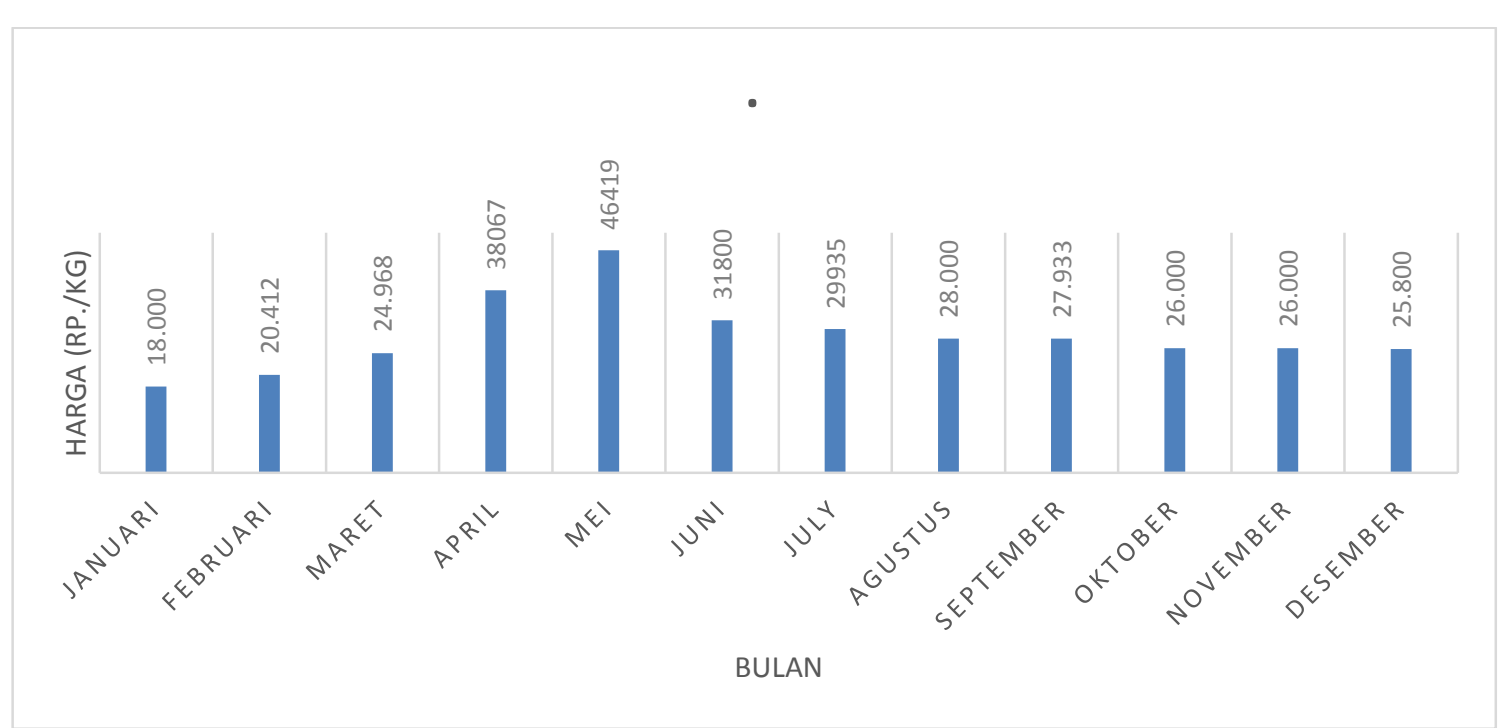

Gambar 1. Perkembangan harga pada Tahun 2019

Sumber : Disperindag Prov. Jambi (2020)

Harga tersebut semakin tidak terkendali dengan adanya penundaan impor Bawang Putih oleh pemerintah. Penundaan Ini kemungkinan besar disebabkan oleh adanya penurunan PDB di tahun 2019 dibandingkan setahun sebelumnya sebagaimana Databoks (2019) yang menunjukkan bahwa ekonomi Indonesia triwulan I 2019 secara tahunan tumbuh 5,07\%. Laju pertumbuhan ini menurun dibandingkan capaian kuartal IV 2018 yang menyentuh $5,18 \%$. Penurunan ekonomi Indonesia yang juga mencerminkan PDB sektor pertanian yang turut menurun ini memiliki korelasi yang positif terhadap impor bawang putih. Sehingga penurunan ekonomi Indonesia di triwulan pertama ini diprediksi juga menurunkan kuantitas impor pada saat itu sebagaimana Indrayani N.K.A. dan Swara I.W.Y.(2014) menyampaikan bahwa impor bawang putih dipengaruhi secara parsial oleh konsumsi dan PDB sektor pertanian yang berpengaruh positif dan variabel yang paling berpengaruh terhadap impor bawang putih adalah PDB pertanian. Pernyataan tersebut didukung juga oleh Ghorbani, M. and M. Motallebi (2009) yang berarti Semakin tinggi pendapatan nasional maka akan meningkatkan impor barang konsumsi karena kebutuhan bawang putih seluruh masyarakat Indonesia hanya mengandalkan impor serta penelitian yang dilakukan juga oleh Kogid et.al.(2011) yang juga menunjukkan bahwa impor secara signifikan positif dipengaruhi oleh pendapatan nasional suatu negara.

Penundaan tersebut menyebabkan gejala peningkatan harga bawang putih kembali meningkat pada Bulan Maret dengan rata-rata harga Rp.24.968 per Kg. Hal ini membuat masyarakat menjadi resah sehingga instansi terkait seperti Dinas Perindustrian dan Perdagangan (Disperindag) Provinsi Jambi membaca keresahan masyarakat yang terjadi oleh adanya fluktuasi harga bawang putih di Bulan Maret. Tindak lanjut Disperindag Provinsi Jambi diteruskan dengan menyampaikan informasi gejala tersebut dengan mengirimkan surat kepada Kementerian Perdagangan Republik Indonesia untuk segera meningkatkan penawaran produk bawang putih. Hal ini disampaikan karena menurut Gatra.com (2020) stok Bawang Putih di Provinsi Jambi saat itu hanya mencapai 25 ton, sedangkan kebutuhan masyarakat Jambi akan Bawang Putih adalah 80 ton per hari

Menurut informasi dari agen grosir bawang putih yaitu PT Maju Jaya sebagai distributor bawang putih di Kota Jambi, operasi pasar ini dilakukan di akhir Bulan Maret sampai April. Menurut Ra (2020) gejolak harga bawang putih terjadi di awal Bulan Februari 2019 sehingga memberatkan masyarakat, Di Bulan Februari harga bawang putih tertinggi sudah menyentuh di atas Rp.50.000 per kilogram. Operasi Pasar Bawang Putih ini dipelopori Dinas Ketahanan Pangan Provinsi Jambi bekerjasama dengan perkumpulan pelaku usaha bawang dan sayuran umbi Indonesia (Bahrindo). Dalam operasi tersebut pihak pemerintah bersama Bahrindo memasok bawang putih sebanyak 3.2 ton dengan harga jual di konsumen Rp. 32.000 per Kg. (Ra.2020). Operasi pasar dilakukan dengan melibatkan instansi agen grosir bawang putih dan pedagang eceran dimana komoditas bawang putih impor akan didistribusikan ke tingkat grosir dengan harga Rp.22.000 per Kg sehingga harga di tingkat konsumen menjadi Rp. 32.000 per Kg. Harga tertinggi yang diciptakan oleh pemerintah ini ditetapkan untuk menarik harga bawang putih yang pada Bulan April sudah menyentuh hampir Rp.50.000 per Kg.

\section{Gambaran Perkembangan Harga Bawang Putih pada Tahun 2019 di Provinsi Jambi.}

Harga merupakan fenomena hasil akhir interaksi antara permintaan dan penawaran di pasaran sebagai satu titik ekuilibrium yang terjadi. Informasi harga bawang putih diambil dari harga beberapa pasar tradisional besar di kota Jambi yaitu Pasar Angso Duo, Pasar Simpang Pulai, dan Pasar Talang Banjar. Harga bawang putih per bulan di pasar tradisional Kota Jambi pada tahun 2019 bergerak dari harga rata-rata harian terendah Rp18.000 per Kg di 
Bulan Januari sampai mencapai harga rata-rata harian tertinggi di Bulan Mei pada Rp.46.419 per Kg, kemudian harga rata-rata harian menurun kembali akhir pada Bulan Desember sebesar Rp.25.800 per Kg dimana rata-rata harga bawang putih per bulan di Tahun 2019 adalah Rp.28.611 per Kg. Kenaikan harga rata-rata harian sampai Bulan Mei mencapai 157,8\% sejak Januari pada Rp.18.000 per Kg menjadi Rp.46.419 per Kg di Bulan Mei, sedangkan penurunan harga setelah mencapai harga rata-rata harian tertinggi di Mei tersebut sampai akhir tahun 2019 itu lebih kecil dari kenaikan yang terjadi sebelumnya. Penurunan ini hanya 65,9\% yaitu dari rata-rata harga Rp.46.419 (Bulan Mei) menjadi Rp.25.800 per Kg (Bulan Desember). Harga rata-rata harian di akhir tahun tidak kembali ke harga rata-rata harian semula (Januari : Rp18.000 per Kg) tetapi hanya menyentuh Rp. 25.800 per Kg. Perkembangan harga bawang putih per bulan pada tahun 2019 dapat lebih jelas dilihat pada Gambar 1. Perkembangan harga harian yang ekstrem terjadi sejak Februari sampai Juli khususnya pada Bulan Mei. Dalam rentang bulan ini terjadi lonjakan harga yang diikuti dengan penurunan dikaitkan dengan operasi pasar yang dilaksanakan di akhir Maret sampai April tetapi harga setelah operasi pasar tetap menunjukkan peningkatan karena pada saat itu walaupun operasi pasar sudah selesai dilaksanakan tetapi masih tetap berhadapan dengan hari besar bulan Ramadan dan hari besar Idul Fitri di Bulan Juni sedangkan pasokan bawang putih mengandalkan impor tidak bisa mengimbangi kecepatan peningakatan permintaan yang terjadi. Aliran masuknya bawang import berjalan dengan lambat sehingga penawaran menjadi lemah untuk menghadapi permintaan yang pada saat itu sedang tinggi. Dalam rentang waktu Bulan Maret sampai Juli tahun 2019, fluktuasi harga yang tertinggi terjadi di Bulan Mei dimana range harga harian bergerak sebesar Rp.70.000 per Kg dengan minimum Rp30.000 dan maksimum mencapai Rp100.000 per Kg. Perkembangan harga bawang putih pada Bulan Mei Tahun 2019 dapat dilihat pada Gambar 2.

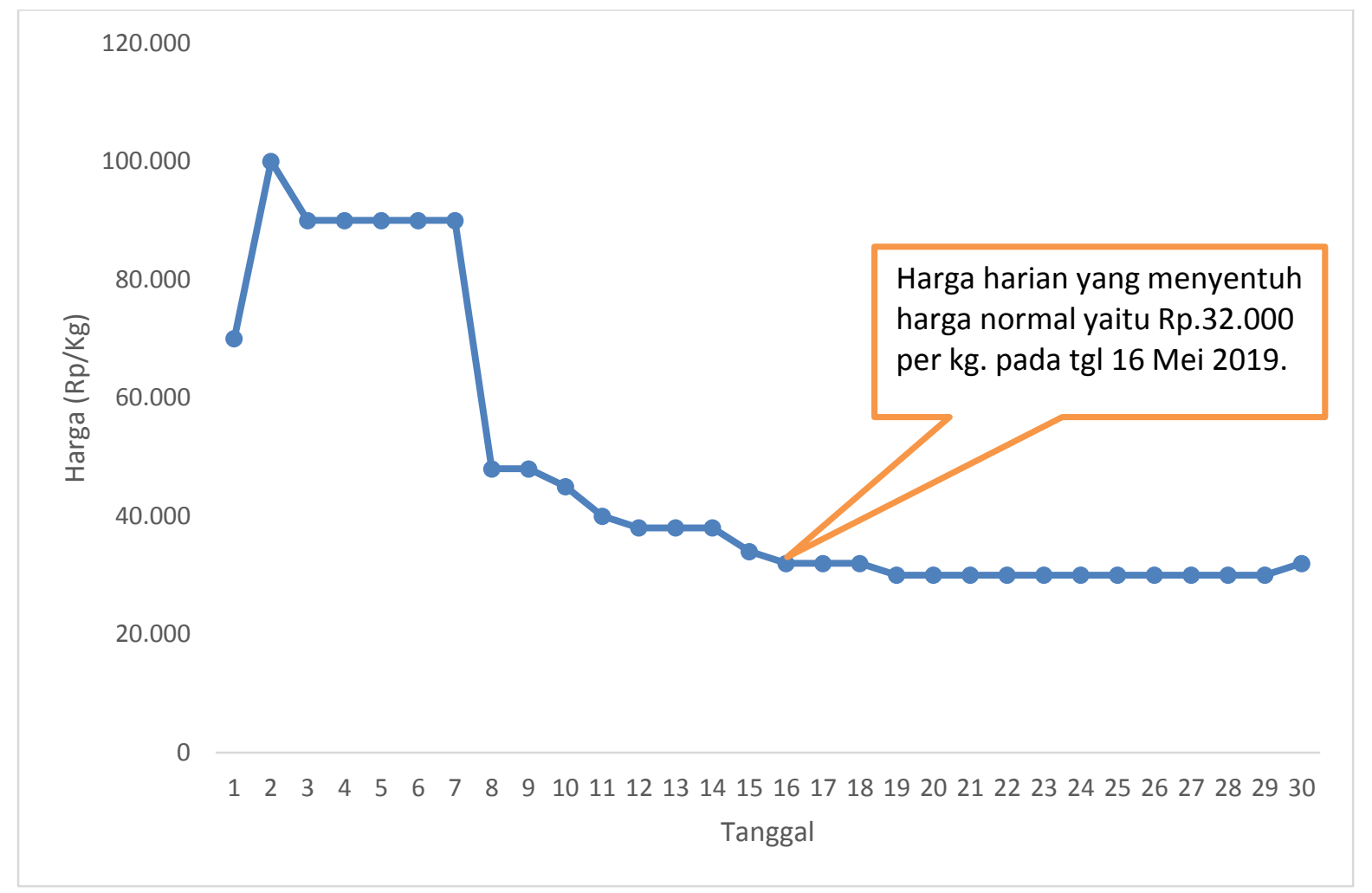

Gambar 2. Perkembangan Harga Bawang Putih Bulan Mei 2029

Sumber : Data Olahan (2020)

\section{Waktu yang Dibutuhkan Dalam Kebijakan Operasi Pasar Untuk Mengembalikan Harga Bawang Putih ke Posisi Harga Normal pada Tahun 2019 di Provinsi Jambi.}

Operasi pasar komoditas bawang putih dilakukan untuk dapat mengembalikan harga yang terlalu tinggi menjadi menurun sesuai dengan harapan atau paling tidak menekan harga agar tidak terlalu tinggi. Telah disampaikan sebelumnya oleh agen grosir bawang putih yaitu PT Maju Jaya sebagai distributor bawang putih di Kota Jambi bahwa pelaksanaan operasi pasar mulai dilaksanakan pada akhir Bulan Maret sampai Bulan April. Operasi pasar dimulai di akhir Bulan Maret di mana Pada saat itu harga baru mulai menyentuh Rp30.000 per Kg seiring dengan waktu di Bulan April terjadi kenaikan mulai di hari ketiga menjadi Rp.32.000 rupiah per Kg naik terus hingga menyentuh angka 5 hampir Rp.50.000 di tanggal 20 April operasi pasar yang berlangsung terusmenerus selama Bulan April bisa menurunkan harga maksimum menyebabkan masyarakat mengambil tindakan memborong produk sehingga permintaan lebih banyak dari stok yang tersedia Bulan Mei operasi pasar berhenti di 
Bulan April sementara permintaan terus melonjak sehubungan dengan hari besar bulan Ramadan di Bulan Mei sehingga di Bulan Mei harga harian sampai menyentuh angka Rp.100.000 per Kg.

Hal yang perlu digarisbawahi adalah operasi pasar yang dilaksanakan mulai akhir Bulan Maret sampai April nampak kesulitan untuk menstabilkan harga ke Rp.32.000 per Kg harga akhir yang terbentuk masih tinggi yaitu Rp.40.000 pada akhir April dan rata-rata pada Bulan April mencapai Rp.38.067 per Kg. Harga rata-rata harian ini masih di atas harga yang diharapkan oleh pemerintah yaitu Rp.32.000 per Kg. Awal pelaksanaan operasi pasar adalah tanggal 30 Maret 2019 sedangkan hasil pengamatan menunjukkan bahwa harga yang menyentuh harga normal yang ditetapkan oleh pemerintah (Rp.32.000 per Kg) dicapai pada tanggal 16 Mei 2019. Perkembangan Harga Bawang Putih Bulan Maret Sampai Juli Tahun 2019 dapat lebih jelas dilihat pada Gambar 3. Pada tanggal 16 Mei 2019 inilah saat yang menunjukkan harga yang tidak signifikan $\left(X^{2}=\right.$ nol yang lebih kecil dari 0,05) sehingga bisa dikatakan bahwa waktu yang dibutuhkan untuk mengembalikan harga bawang putih di lapangan ke harga normal yang ditetapkan oleh pemerintah adalah 50 hari atau hampir dua bulan sejak awal pelaksanaan operasi pasar.

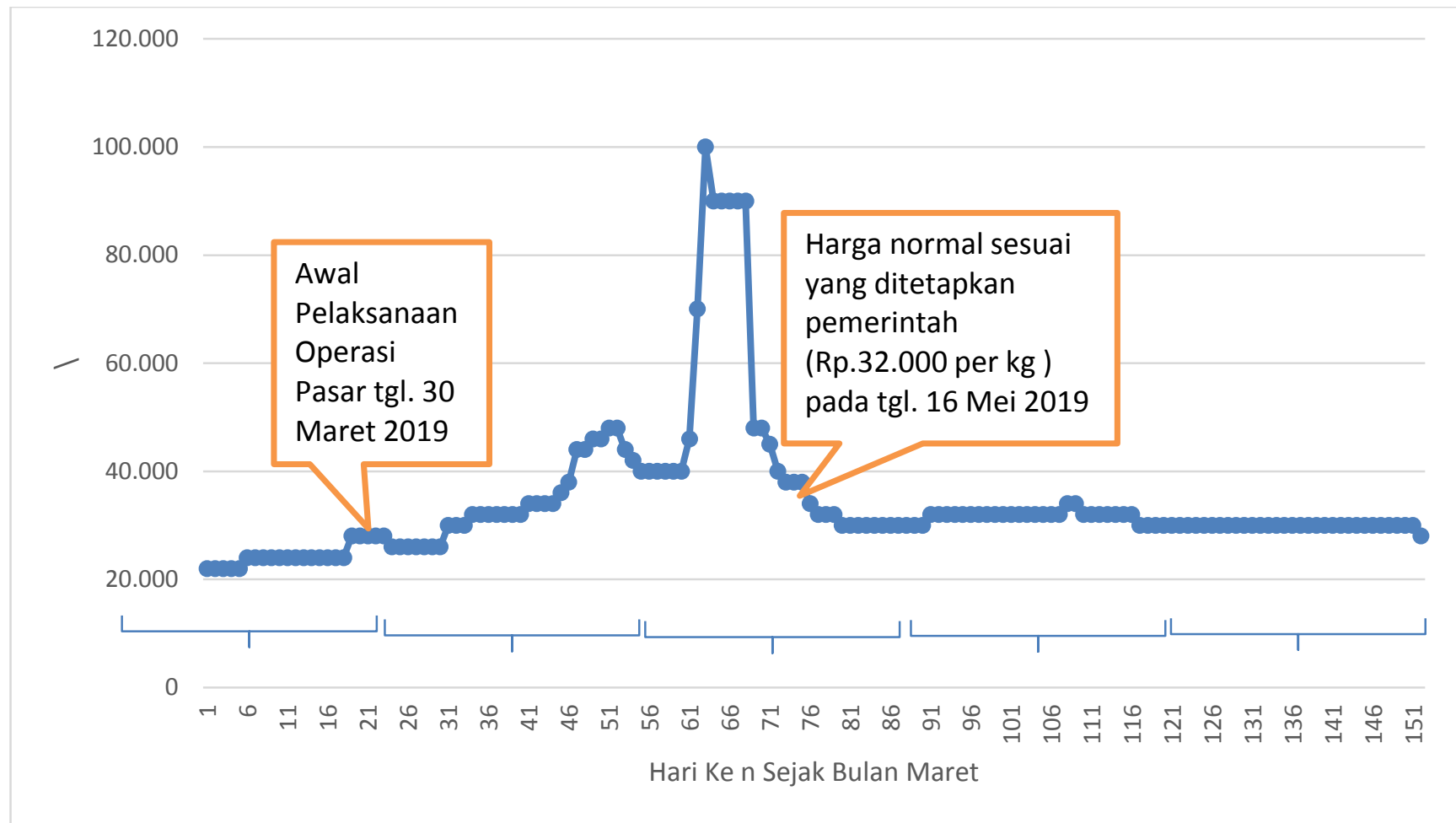

Gambar 3. Perkembangan Harga Bawang Putih Bulan Maret Sampai Juli Tahun 2019 Sumber : Data Olahan (2020)

Waktu ini bisa dikatakan cukup lama karena banyak kekuatan yang turut menentukan pembentukan harga bawang putih di lapangan sehingga pelaksanaan operasi pasar kurang efektif. Kekuatan yang turut menentukan pembentukan harga bawang putih di lapangan diantaranya adalah selain redahnya kemampuan produksi bawang putih di tingkat regional, juga berhadapan dengan Bulan Ramadan, hari besar Idul Fitri, sehingga mendorong kenaikan permintaan. Kenaikan permintaan ini kurang diimbangi dengan penawaran yang memadai karena selain stok yang tipis juga lambatnya proses aliran import bawang putih dari Cina.

\section{KESIMPULAN}

Pelaksanaan operasi Pasar Bawang Putih diawali dengan adanya perhatian Dinas Perindustrian dan Perdagangan (Disperindag) Provinsi Jambi terhadap keresahan masyarakat yang terjadi oleh adanya fluktuasi harga bawang putih di Bulan Februari 2019. Hal ini ditindaklanjuti oleh Disperindag Provinsi Jambi dengan penyampaian surat permintaan supply bawang putih kepada Kementerian Perdagangan Republik Indonesia. Menurut informasi dari agen grosir bawang putih yaitu PT Maju Jaya sebagai distributor bawang putih di Kota Jambi, operasi pasar ini dilakukan di akhir Bulan Maret sampai April. Operasi Pasar ini dipelopori Dinas Ketahanan Pangan Provinsi Jambi bekerjasama dengan perkumpulan pelaku usaha bawang dan sayuran umbi Indonesia (Pusbarindo) serta melibatkan instansi agen grosir bawang putih dan pedagang eceran dimana komoditas bawang putih impor sejumlah 3,2 ton telah didistribusikan ke tingkat grosir dengan harga Rp.22.000 per Kg sehingga harga di tingkat konsumen menjadi Rp. 32.000 per Kg. 
Informasi harga bawang putih diambil dari harga beberapa pasar tradisional besar di kota Jambi yaitu Pasar Angso Duo, Pasar Simpang Pulai, dan Pasar Talang Banjar. Harga rata-rata harian terendah Rp.18.000 per Kg (Bulan Januari) dan rata-rata harian tertinggi adalah Rp.46.419 per Kg (Bulan Mei). Kenaikan harga rata-rata harian mencapai 157,8\% sejak Januari (Rp.18.000 per Kg) sampai Bulan Mei (Rp.46.419 per Kg), sedangkan penurunannya setelah mencapai harga rata-rata harian tertinggi di Mei sampai akhir tahun 2019 lebih kecil dari kenaikan yang terjadi sebelumnya yaitu hanya 65,9\% (dari rata-rata harga Rp.46.419 di Bulan Mei menjadi Rp.25.800 per Kg di Bulan Desember). Harga bawang putih setelah operasi pasar tetap menunjukkan peningkatan karena selain adanya bulan Ramadan dan hari besar Idul Fitri juga pasokan impor bawang putih yang lambat. Dalam rentang waktu Bulan Maret sampai Juli tahun 2019, fluktuasi harga yang tertinggi terjadi di Bulan Mei dimana range harga harian bergerak sebesar Rp.70.000 per Kg dengan minimum Rp30.000 dan maksimum mencapai Rp100.000 per Kg.

Waktu yang dibutuhkan untuk mengembalikan harga bawang putih di lapangan ke harga normal yang ditetapkan oleh pemerintah adalah 50 hari atau hampir dua bulan sejak awal pelaksanaan operasi pasar. Untuk menambah kekuatan pasokan regional maka perlu melaksanakan program khusus penanaman bawang putih di Provinsi Jambi khususnya sehingga mengurangi ketergantungan terhadap import. Sebaiknya bawang putih dimasukkan komoditas yang ditangani oleh Bulog Provinsi Jambi.

Databoks. 2019.Sektor Industri Sumbang 20 Persen PDB.

\section{DAFTAR PUSTAKA}

https://databoks.katadata.co.id/datapublish/2019/05/06/sektor-industri-sumbang-20-persen-pdb. Diakses tanggal 20 Juli 2020.

Ghorbani, M. and M. Motallebi.2009. Application Pesaran And Shin Method For Estimating Irans' Import Demand Function. Journal of Applied Sciences. Vol. 9 No.6:1175-1179.

Indrayani N.K.A. dan Swara I.W.Y.(2014). Pengaruh Konsumsi, Produksi Kurs Dollar AS dan PDB Pertanian terhadap Impor Bawang Putih Indonesia. E-Jurnal EP Unud, E Vol. 3, No. 5, 209-218 .Mei 2014.

Kementan Direktorat Holtikultura.2017.Berapa Volume dan Nilai Impor Bawang Putih. https://databoks.katadata.co.id/datapublish/2017/05/30/berapa-volume-dan-nilai-impor-bawang-putih . 1-102019

Kogid, Mori, Dollah Mulok, Kok Sook Ching, and Jaratin Lily .2011. Does Import Affect Economic Growth in Malaysia. The Empirical Economics Letters.Vol 10 No.3:297- 307. Malaysia: School of Business and Economics, Universiti Malaysia Sabah

Ra.2020. Operasi Pasar Satgas Pangan Jambi Jual Bawang Putih. Jack tv.co.id. Diakses 2 Agustus 2020.

Samuel Pablo.2019. Impor Bawang Puth Nyaris 100\%. Bagaimana Produksi RI. https://www.cnbcindonesia.com/news/20190425194417-4-68960/impor-bawang-putih-nyaris-100-bagaimanaproduksi-ri. CNBC Indonesia. Diakses 2-10-2020.

Sudradjat SW, M. 1999.Statistik Non Parametrik.Fakultas. Pertanian, Universitas Padjadjaran. Jatinangor.

Yustinus Andri DP.2019. Impor Bawang Putih Melonjak pada Juli 2019. https://ekonomi.bisnis.com/read/20190815/12/1137004/bps-impor-bawang-putih-melonjak-pada-juli-2019 Bisnis.com. Diakses 1-10-2020.

Zulkifli. 2019. Harga Bawang Putih Meroket Disperindag Provinsi Jambi Sebut Stock Menipis Dan Sudah Surati Kemendag.Tribun Jambi. https://jambi.tribunnews.com/2019/05/02/harga-bawang-putih-meroketdisperindag-provinsi-jambi-sebut-stock-menipis-dan-sudah-surati-kemendag.Diakses12-11-2019. 